\title{
コーパスアノテーション一新しい可能性と共有化にむけての試み一
}

アノテーションとはテキストに対する注釈づけのことである。言語処理の分野ではその注釈 を教師あり機械学習のための学習・評価データとして利用することが多い. その昔, 規則に基 づく言語処理から統計的機械学習に基づく言語処理へと移り変わる頃，一つの研究機関におい て言語学者と情報工学研究者が寄り添いながらテキストに対しアノテーションを行い, 言語処 理研究を進めていた.アノテーションは共有化され, それが共通のベンチマークとして用いら れるようになるにつれて, 若い情報工学研究者はアノテーションの背景にある深い洞察を無視 して，陸上のトラック競技のようにベンチマーク上での数值を追い求めるようになる．質的な 考察は場当たり的なものが多く，数值が出ない場合にベンチマークデータが悪いと評するもの まであらわれる。一方，アノテーションを整備する研究については，あまり評価されない時代 が続いていた，言語処理において人手が介在することが定量的に評価するうえで公正ではない という考え方が蔓延していた。 ベンチマーク上の公正な評価を求める一方, そのベンチマーク を作成する過程で行われる人間の知的作業についてはほとんど評価されてこなかった。

その知的作業においては様々なことが行われる。

たとえば，最初に決めた基準に適合しない事例が現れる，その都度，過去の文献をひもとき， その現象が言語学においてどのように扱われているのかを見極め, 最初の基準を破棄して新た に基準を策定するのか, 既存の基準の拡大解釈や特殊事例として扱うのか, 基準の見直しの判 断が迫られる，基準の見直しが発生した場合には，既にアノテーションを施した部分に修正が 必要になる。一般にコーパスアノテーションは複数の作業者により実施され，異論があるにせ よアノテーションの一貫性がほぼ唯一の定量的な評価指針となる。このため, 基準の修正はア ノテーション従事者全てで共有する必要がある。作業者の多くは人文系の日雇いもしくは時間 単価で働くパート労働者であり，基準の見直しのたびに動機づけを含めた組織運営が必要にな る。有能な作業者は, 説明しがたい言語現象の本質を見極め, 組織をまとめながら, 基準を練 り上げていく.

基準や規則の作成・保守に膨大な労力が必要であるが, 単純な規則を反映させる機械処理, 作 業者が実際にアノテーションを行う際に利用する GUI ツール, 複数の作業者で同時に作業可能 なデータベースインフラ, 基準などを共有するためのコラボレーションツールやグループウェ ア, 在宅作業のための遠隔地作業支援システム, 複数の版を管理するバージョン管理システム, スタンドオフによる共有化などさまざまな技術を駆使しながら，アノテーション整備が進めら れている.このような現場で利用されている方法論は, 従来, 研究者同士の局所的な情報交換 により伝えられてきた。

近年, このような方法論の情報交換がよりオープンな場で行われ，コーパスアノテーション の再評価の機運が高まっている. 2013 年の第 19 回年次大会では, チュートリアル「テキストア 
ノテーション：現状と今後の方向性」とテーマセッション「コーパスアノテーションの可能性 と共有化」とが独立に提案され, 採用された。これはアノテーションに関する議論の場の必要 性を示す出来事であったといえる。本特集号では，アノテーションの要素技術である，標本同 定・仕様策定・標準化・作業者教育・アノテーション支援環境・既存のアノテーションとの重 ね合わせ・スタンドオフによる公開・版管理などについての方法論についての論文を募集した. その結果，合計 14 件の投稿があり，2 件著者都合の取り下げがあったが，残り 12 件の中から 9 件の論文を採録した（採録率 $75 \%$ ），募集した論文の性質上いずれも大部の原稿であり，査読は 根気のいる作業であったが， $89 \%$ の査読者が限られたスケジュールのなか，期限内に査読して いただいた，多忙の中，編集作業や査読に協力いただいた編集委員，査読委員，編集に携わっ た全ての方に感謝の意を表したい.

本特集号を通して，コーパスアノテーションに従事する研究者においては，アノテーション を論ずるにあたり, 何が議論の対象になっているのか, 論点を整理する一助となればと考えて いる.コーパスアノテーションに従事しない研究者においては，コーパスアノテーション現場 において，言語の制約と曖昧性の中で人文系パート労働者によって繰り広げられる美しい知的 作業の一端を知っていただければ無上の喜びである.

\section{浅原正幸（国立国語研究所） 前川喜久雄（国立国語研究所）}

\section{Corpus Annotation-An Attempt Toward New Possibilities and Sharing}

Annotation refers to the addition of notes or comments to a text. It is common in the field of language processing to use such notes or comments as learning or evaluation data for supervised machine learning. In recent decades, as the field of language processing has shifted from rulebased language processing to statistical machine learning-based language processing, linguists and information technology researchers have gathered together in a single research institution to annotate text and carry out research. As these annotations came to be shared and used as a common benchmark, younger researchers in the field of information technology also came to ignore the deep insights behind annotative methods and started pursuing numerical values as a benchmark, just like in athletic events.

Qualitative examinations were mostly carried out in an ad hoc fashion, to the extent that some studies that did not produce numerical values were considered low or inadequate in benchmark data. In addition, for a long time, research that improved annotation was not valued much. 
It was commonly believed that manual intervention was not a fruitful method for quantitative evaluation in language processing. While correct evaluation of the benchmark was sought, the intellectual work carried out by humans in the process of creating the benchmark was not valued much.

This intellectual work involves various activities. For example, when a case does not fit a standard that was set initially, one has to read through past literature, ascertain how the phenomenon is dealt with in linguistics, and then make a decision on revising the standard - that is, whether the initial standard should be abandoned and a new one developed, or whether the current case should be treated as an example of a different situation or an exception to the existing standard. When a standard needs to be revised, it becomes necessary to correct texts that are already annotated. Corpus annotation is generally carried out by a number of people working in tandem, and consistency in the annotations, even if there are differences of opinion, is virtually the only quantitative assessment methodology available. For this reason, corrections to the standards have to be shared with all the people involved in the annotation. Many of these people are part-time employees from the humanities field, hired on a daily or hourly basis. It is therefore essential to have a well-organised team with members who are motivated to work effectively whenever a revision of the standard is required. Competent workers will ascertain the essence of any hard-to-explain language phenomenon and then work together in coordination to refine the standard.

Creating or maintaining a standard or rule requires huge amounts of work. Improvements in annotation are being made by employing various technologies like machine processing that can reflect simple rules, GUI tools that workers use to actually carry out annotation, database infrastructure that allows a number of people to work simultaneously, collaboration tools or groupware for sharing information like corrections, remote work support systems for working at home, version control systems for managing various versions, and sharing through standoff annotation (that is, annotation that resides in a different place than the annotated text; compare inline annotation). Methodologies such as these that are employed in annotation work have traditionally been conveyed or taught through local information exchanges between fellow researchers.

In recent years, however, exchange of information on such methodologies has come to be conducted in a more open environment, and the re-evaluation of corpus annotation approaches as a whole is gaining momentum. At the 19th annual meeting of the Association for Natural Language Processing, held in 2013, a tutorial on "Text Annotation: Present and Future Trends" and a theme discussion on "Possibilities and Sharing of Corpus Annotation" were independently proposed and adopted. It can be said that these developments indicate the need for a platform 
for debate on annotation. For this special edition, therefore, we invited papers on methodologies pertaining to annotation, including sample identification, specification development, standardisation, worker education, annotation support environments, superimposition on existing annotations, disclosure through standoff, and version management. We received 14 submissions; two of these were withdrawn, and nine of the remaining 12 were accepted (acceptance rate: $75 \%$ ). All the papers received were high in quality and peer review was very challenging, but $89 \%$ of the reviewers submitted their reviews within the time limit, despite their busy schedules. We would like to express our gratitude to the members of the editorial committee, the peer-review committee, and all others who helped with the editing and review.

We hope that this special edition will help organise and unify the on-going debates among researchers engaged in corpus annotation. As for researchers who are not engaged in corpus annotation, we hope this special edition will help them get an idea of the beautiful intellectual work being undertaken by part-time humanities workers within the constraints and ambiguities of the corpus annotation field.

Masayuki Asahara (National Institute for Japanese Language and Linguistics) Kikuo Maekawa (National Institute for Japanese Language and Linguistics) 